\title{
Supporting Elementary Teacher's Reflections on Equity in CS Education
}

\author{
Florence Sullivan \\ Teacher Ed. Curr. Studies \\ University of Massachusetts \\ Amherst, MA USA \\ florence@umass.edu \\ Sneha Veeragoudar \\ Computer Science \\ University of Massachusetts \\ Amherst, MA USA \\ sveeragoudar@umass.edu
}

A Case Study Approach

ts

\begin{abstract}
The dearth of women and people of color in the field of computer science is a well-documented phenomenon [1]. Following US President Barak Obama's 2016 declaration of the need for a nationwide CS for All movement in the US [2], educators, school districts, states and the US-based National Science Foundation have responded with an explosion of activity directed at developing computer science learning opportunities in $\mathrm{K}-12$ settings. A major component of this effort is the creation of equitable CS learning opportunities for underrepresented populations. As a result, there exists a strong need for educational research on the development of equity-based theory and practice in CS education [3]. This poster session reports on a work-in-progress study that uses a case study approach to engage twenty in-service elementary school teachers in reflecting on issues of equity in CS education as part of a threeday CS professional development workshop. Our work is unfolding in the context of a four-year university/district research practice partnership in a mid-sized city in the Northeastern United States. Teachers in our project are working to co-design integrated CS curriculum units for K-5 classrooms. We developed four case studies, drawn from the first year of our project, that highlight equity challenges teachers faced in the classroom when implementing the CS lessons. The case studies follow the "Teacher Moments" template approach created by the Teaching Systems Lab in Open Learning at MIT [4]. In this approach, teachers have the opportunity to reflect on the case study individually, then share their reflections in a small group. The work culminates in large group discussion of the case

Permission to make digital or hard copies of all or part of this work for personal or classroom use is granted without fee provided that copies are not made or distributed for profit or commercial advantage and that copies bear this notice and the full citation on the first page. Copyrights for third-party components of this work must be honored. For all other uses, contact the Owner/Author ICER'19, August 12-14, 2019, Toronto, ON, Canada,

(C) 2019 Copyright is held by the owner/author(s).

ACM ISBN 978-1-4503-6185-9/19/08.

DOI: http://dx.doi.org/10.1145/3291279.3341208
\end{abstract}

\author{
Catherine Tulungen \\ Teacher Ed. Curr. Studies \\ University of Massachusetts \\ Amherst, MA USA \\ ctulungen@umass.edu \\ Emrah Pektas \\ Teacher Ed. Curr. Studies \\ University of Massachusetts \\ Amherst, MA USA \\ epektas@umass.edu
}

studies. The goal of the activity is to deepen elementary teachers' reflections and discussions on how to create equitable computer science learning opportunities for elementary school students. We present preliminary findings in our poster session.

\section{CCS CONCEPTS}

- Social and Professional topics - K-12 Education - Social and Professional topics - Race and Ethnicity $\bullet$ Social and Professional topics - Gender

\section{KEYWORDS}

Equity, Elementary Education, Computer Science Education, Case Study

\section{ACM Reference format:}

Florence R. Sullivan, Sneha Veeragoudar, Catherine Tulungen and Emrah Pektas. 2019. Supporting Elementary Teacher's Reflections on Equity in CS Education: A Case Study Approach. In Proceedings of International Computing Education Research (ICER'19), Conference August 12-14, Toronto, ON, Canada. ACM, New York, NY, USA, 1 page. https://doi.org/10.1145//3291279.3341208.

\section{ACKNOWLEDGMENTS}

This work is supported by the National Science Foundation of the United States under Grant No.: DRL-8637086.

\section{REFERENCES}

[1] National Science Foundation. 2015. Women, minorities and persons with disabilities in science and engineering 2015. National Center for Science and Engineering Statistics. Retrieved from http://www.nsf.gov/statistics/wmpd/

[2] Tom Smith. 2016. Computer science for all. White House Blog. Retrieved online https://obamawhitehouse.archives.gov/blog/2016/01/30/computerscience-all.

[3] Jane Margolis. 2008. Stuck in the shallow end: Education, race, and computing. Cambridge: MIT Press.

[4] The MIT Teaching Systems Lab. 2019. Teacher moments. Retrieved online https://teachermoments.teachingsystemslab.org/equity?email 